\title{
COMPETITION IN HEALTH CARE
}

Reforming the NHS 
ECONOMIC ISSUES IN HEALTH CARE

General editors

Professor Gavin Mooney

Dr Alistair McGuire

Institute of Social Medicine

University of Copenhagen

Centre for Socio-Legal Studies

2200 Copenhagen N, Denmark and Pembroke College

University of Oxford

Oxford OX2 6UD, England

The Challenges of Medical Practice Variations

Edited by Tavs Folmer Andersen and Gavin Mooney (1990)

Competition in Health Care: Reforming the NHS

Edited by A.J. Culyer, Alan Maynard and John Posnett (1990)

Strategies of Health Financing in Developing Countries

By Guy Carrin (1991)

Private Exchange and Public Interest

By John Forbes (1991)

Why Wait? Tackling Waiting Lists in the NHS

Edited by Stephen J. Frankel and R.R. West (1991)

Just Managing-Power and Culture in the NHS

By Stephen Harrison, David J. Hunter and Gordon Marnoch (1991)

Dental Care: An Economic View

By David Parkin and Brian Yule (1991) 


\title{
COMPETITION IN HEALTH CARE \\ Reforming the NHS
}

\author{
Edited by \\ A.J. Culyer \\ Professor of Economics \\ University of York, UK \\ Alan Maynard \\ Director, Centre for Health Economics \\ University of York, UK \\ and

\section{John Posnett} \\ Senior Lecturer in Health Economics \\ University of York, UK
}

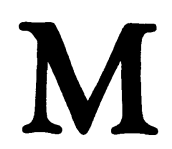

Macmillan Education 
(C) The Editors and Contributors 1990

All rights reserved. No reproduction, copy or transmission of this publication may be made without written permission.

No paragraph of this publication may be reproduced, copied or transmitted save with written permission or in accordance with the provisions of the Copyright, Designs and Patents Act 1988, or under the terms of any licence permitting limited copying issued by the Copyright Licensing Agency, 90 Tottenham Court Road, London W1P 9HE.

Any person who does any unauthorised act in relation to this publication may be liable to criminal prosecution and civil claims for damages.

First published 1990 by

THE MACMILLAN PRESS LTD

Houndmills, Basingstoke, Hampshire RG21 2XS

and London

Companies and representatives

throughout the world

ISBN 978-0-333-55169-1

DOI 10.1007/978-1-349-21052-7

ISBN 978-1-349-21052-7 (eBook)

A catalogue record for this book is available

from the British Library

Reprinted 1992 


\section{Contents}

Acknowledgements vi vi

Notes on the Contributors vii

Reforming Health Care: an Introduction to the Economic Issues 1

A.J. Culyer, Alan Maynard, John Posnett

1. Hospital Behaviour and Competition 12

A.J. Culyer and John Posnett

2. Whither the Private Health Care Sector?

Carol Propper and Alan Maynard

3. NHS Resourcing: A Financial and Economic Analysis David Mayston

4. Information Systems and the White Paper Proposals Peter Smith

5. Managing Capital Resources in the NHS

David Mayston

6. Ethics, Clinical Freedom and the Doctors' Role Alan Williams

7. RAWP is Dead: Long Live RAWP

Roy Carr-Hill

8. The Challenge of Community Care Reform

K.G. Wright

9. Evaluating the Reform of the NHS

John Brazier, John Hutton and Richard Jeavons

10. Research Implications of the NHS Review Alan Williams 


\section{Acknowledgements}

Thanks for financial support are due to the Department of Health (Chapters 1 and 8) and the Economic and Social Research Council, funded under project WB04250012 (Chapters 3 and 5). The editors heartily thank Lorna Foster for her editorial contributions and the extraordinary patience and forbearance she has shown despite constant revisions by contributors. Thanks also go to the secretarial staff of the Centre for Health Economics, University of York, under the capable direction of Sal McNeil. 


\section{Notes on the Contributors}

John Brazier is a Lecturer in Health Economics in the Medical Care Research Unit, Department of Community Medicine, University of Sheffield, formerly Research Fellow in the York Health Economics Consortium.

Roy Carr-Hill is a Senior Research Fellow in the Centre for Health Economics at the University of York.

A.J. Culyer is Professor of Economics and Head of the Department of Economics and Related Studies at the University of York.

John Hutton is a Senior Research Fellow in the Centre for Health Economics at the University of York.

Richard Jeavons is Director of Research Management at the Northern General Hospital, Sheffield, formerly Deputy Director of the York Health Economics Consortium.

Alan Maynard is Professor of Economics and Director of the Centre for Health Economics at the University of York.

David Mayston is Professor of Public Sector Economics, Finance and Accountancy at the University of York.

John Posnett is a Senior Lecturer in Health Economics and Director of the Graduate Programme in Health Economics at the University of York.

Carol Propper is a Lecturer in Economics, University of Bristol and formerly Research Fellow, Centre for Health Economics, University of York.

Peter Smith is a Lecturer in Economics, Finance and Accountancy at the University of York.

Alan Williams is Professor of Economics in the Department of Economics and the Centre for Health Economics at the University of York.

Ken Wright is a Senior Research Fellow and Deputy Director of the Centre for Health Economics at the University of York. 